\title{
Attitude realization in news reports: An interpretation through an appraisal analysis
}

\author{
Saira Asad ${ }^{1 *}$, Siti Noor Fazelah Binti Mohd Noor ${ }^{1}$, Rohmani Nur Indah ${ }^{2}$, and \\ Lutfan Bin Jaes ${ }^{3}$
}

\author{
${ }^{1}$ Faculty of Applied Sciences and Technology (FAST), Centre of Language Studies (CLS), \\ Universiti Tun Hussein Onn Malaysia (UTHM), Malaysia \\ ${ }^{2}$ Sastra Inggris, Fakultas Ilmu Budaya, Universitas Islam Negeri Maulana Malik Ibrahim, Malang, Indonesia, \\ ${ }^{3}$ Faculty of Social Science, Centre for General Studies and Co-curricular Universiti Tun Hussein Onn Malaysia \\ (UTHM), 86400, Parit Raja, Batu Pahat, Johar, Malaysia.
}

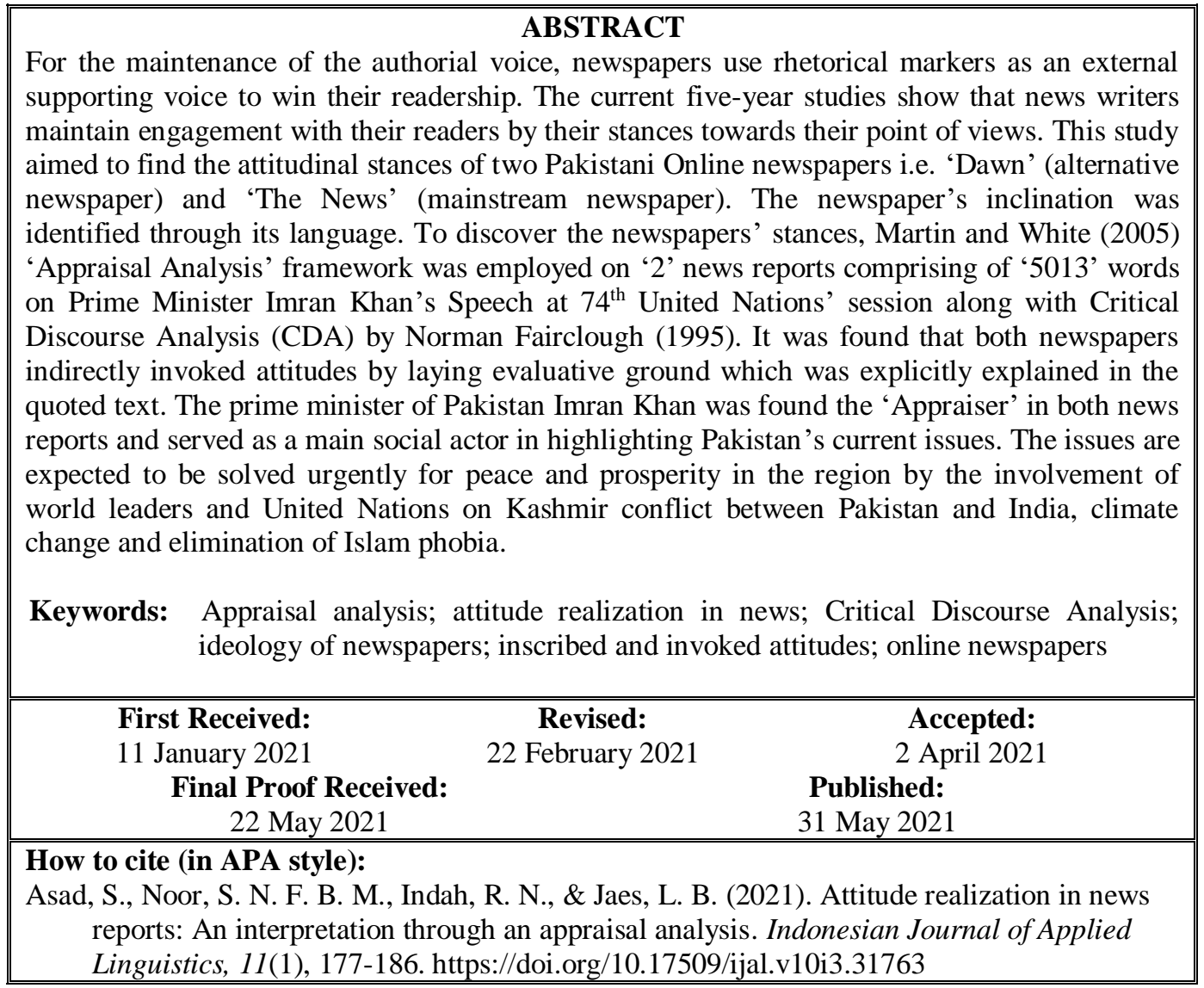

\section{INTRODUCTION}

Language has grammatical and lexical items concerning its context (Halliday, 1999). The news media is considered as an institution of politics where politics gets mediatized and represented by the language/text (Schudson, 2002). In politics, communication and media have a strong relationship. In today's world, the coverage of newspapers of political news generally depicts the ideology of news institutions as different stances of the same news in different newspapers show various viewpoints. The text of the newspaper has the power to depict that viewpoint that is known as social life spaces within processes by the representation of the world in the cognitive and social interaction processes (Fairclough, 1995).

In the whole process of cognitive and social interaction motivates and enforces the reader to find out the hidden meaning behind the text representation which construes the power relation

\footnotetext{
*Corresponding Author

Email: saira.asad2011@gmail.com
} 
among news, journalist and news institution. It is seen that background of news generally required by readers to be understood the current development of news for better understanding. The development of power relation enforces the reader to find out the reasons behind the representation of news. According to Foucault's (1980) notion of power, the definite perspective of issue constructs the semantic reality that serves the particular social and historical interests in that context (van Leeuwen, 2008). It is observed that media organizations and their employees make their internal policies often seen by considering context, public opinion and giving favor to particular politicians to keep their interests at first. In media discourse, the power relations are constructed by the participants' roles and at deeper level it concerns with ideology (Haig, 2012). Thus, the analysis of text leads to determine the ideology of news instituition. Adopting the mediatized process of political communication helps the deliberative legitimized process in society (Habermas, 2006). The role of media in today's society is a 'political actor' (Page, 1996). Media and politics are dependent on each other (Bagdikian, 2007). For knowing the influence and factors that affect media text, there is a need to do in-depth analysis of text.

For the analysis of text, Critical Discourse Analysis (CDA) employed that explores the hidden ideologies behind the texts and relies on the notion that language plays a vital role in the discourse. For finding out the ideology, the hard news is selected that is explained as 'impartial' and 'objective' narration of reality by the construction of ideology (Allan, 2010). The article looks for discourses' representation in news reports in Pakistani media culture by the 'Appraisal Analysis'. To attain this aim, 'hard news' of 'Dawn' (alternative newspaper) and 'The News' (mainstream online newspaper) is selected on Prime Minister Imran Khan's speech in 74th United Nations' session held in New York.

Critical Discourse Analysis (CDA) is considered a technique of exploring unseen ideologies in the text in a social context. Texts are defining terms of social practices (Fairclough, 1995) that are related to social relations and the historical context (Janks, 1997). The central concern of CDA is to de-mystify the ideologies and power by the systematic evaluation of semiotic data (Wodak \& Meyer, 2009) that can also represent ideologies through the lexico-stylistic choice of the texts (Ononye, 2017).

Text was taken as influenced by its context that depicts ideology. The analysis of text conducted by considering CDA along 'Attitude' analysis. CDA critically analyzes the micro-events as in the existing study of online media text and macro structures, including the media influences that got their shape from context (Thomas \& Selimovic, 2015). It is considered that language socially emerges with interaction and it has an active identity (Richardson, 2007). It was to find that how discourse was used and language received its shape. Wodak and Meyer (2009) stated that discourse is an institutionalized path of talking that reshapes, reinforces, and regulates the action that exerts power. The application of CDA comprises textual analysis of three dimensions i.e. analyzing the object (situational, societal); the process of production and interpretation; and the historical/context state and description. In this way, CDA creates a relation of language with ideology and power that explains the relationship between an event and social structure (Wodak, 2006). Critical Discourse Analysis theory suggests that texts cannot be separated from assessing the discoursal practices of institutions (Fairclough, 1995).

The present study focuses to answer three research objectives. First, it aims to find the positive/negative inscribed and invoked attitudinal stances in online Pakistani newspapers in the representation of Prime Minister Imran Khan's speech in 74th United Nations' session. Second, it identifies the objectivity of the news representation in 'Dawn' and 'The News' by their attitudinal stances. Third, it differentiates the attitudinal similarities and differences among both newspapers by their frequencies. It is found that Imran Khan's 74th UN session's speech has not been analyzed from the 'Attitude' analysis earlier and no comparative analysis of Pakistani online alternative and mainstream newspapers is found. Thus, this study fills the gap methodologically and analytically.

To answer the research objectives, the background of the study is throwing light at the Pakistani current political situation and its current alarming problems that are required to be solved by the involvement of other countries. Pakistan came into being on 14th August 1947 after getting independence from British rule. After independence, India and Pakistan emerged as two neighboring nations on the world map. Since 1989, it is seen that the military insurgency is on increase in Jammu and Kashmir which is a main tussle between India and Pakistan. It is a dispute since the rule of the British ended in India in 1947. At that time British did not plan of five hundred semi-independent states' future as left the decision on then Royal princes to decide on the majority population with whom they wanted to be. Due to religious, geographic location and cultural values, the states were given authority to join India or Pakistan (Khan, 1994). Jammu and Kashmir were the ones where the majority were Muslims but Prince Hari Singh, who had received the throne in 1925 of Kashmir and till 1947 remained the reigning monarch decided to be with India.

Being a Hindu, Prince Hari Singh neglected Muslims of Kashmir to be united with Pakistan 
where the vast majority was Muslim. Jammu had the majority of Hindus and Ladakh and Baltistan were Buddhist (Khan, 1994). On this decision, Pashtun Tribesman invaded Kashmir and defeated the forces of Hari Singh. On the demand of help from then Governor-General of India, Lord Mountbatten was advised to sign the Instrument of Accession of joining all princely state into Dominion of India including Kashmir, Ladakh, Northern Areas, TransKarakoram Tract and Aksai Chin and declared an emergency. Until now, India and Pakistan are on fighting terms on the issue of Kashmir. A significant number of military forces from Pakistan and India are occupying the areas of Kashmir that are known as 'Azad Kashmir' in Pakistani territory and 'Indian Occupied Kashmir' on the Indian side which is separated by 870 miles of 'line of control' (Khan, 1994).

A new government under the leadership of Prime Minister Imran Khan was established by inheriting many economic and financial crises from the past government. For catering the issues of money laundering, climate and water are priority issues to be solved for the government instead of involving in wars which is time to time stated by the current government. From time to time the terrorist groups' formation has also been blamed on Pakistan. Pakistan has already faced a lot of losses in which 75,000 causalities and faced more than $\$ 123$ billion economically (Masood, 2018).

In the case of press media in Pakistan, it is considered a powerful medium. However, Pakistani press media enjoys freedom of speech. Still, restrictions apply when there are concerns about security, religion, judiciary and armed forces of the country, and coverage becomes a hindrance in dealing with sensitive issues. 'Dawn' was established in 1941 by the founder of Pakistan, Quaid-e-Azam Mohammad Ali Jinnah. It remains as a liberal and alternative newspaper. 'Dawn' has earned its name by representing disputed, sensitive and leftist issues in society (Malik \& Iqbal, 2011). It belongs to 'Herald Publication' which is one of the leading publishing private companies. On the other hand; 'The News' always played a complicated role in society by its inclination towards 'Lawyers Movement' in 2007-2009 showing resistance towards the military government of General Pervez Musharraf and inclination towards Pakistan Muslim League. By its role in that era, 'The News' has earned its reputation as a mainstream newspaper. It is being published by the largest publishing company in the country 'Jang Publications' established in 1991. 'The News' also has to credit the huge readership in-country by having 140,000 circulations per day. Both newspapers are known for their functioning and differ from each other as per their ideologies.

In recent times, the online newspaper has become an accessible and efficient way of dissemination of information and source of information retrieval which has created user-user interactivity as a social requirement of today (Ksiazek et al., 2016). Online newspapers receive their shape by the institution's norms, not by the internet (Jóhannsdóttir, 2018). By analyzing the past five years' research on 'Appraisal Analysis' (20152019), Zaidi (2016) was of the view that the violence reporting on Shias was found biased in Pakistani newspapers' coverage as mostly the issues denied for coverage. He analyzed it by the semantic structure of 'hard news' of Pakistani newspapers. He further added that news reporting influenced by other factors of society so; there is a need for 'transformative voice' for opposing the practices of journalism (Zaidi, 2016).

Asad et al. (2019c) employed Critical Discourse Analysis (CDA) with Systemic Functional Linguistics (SFL) on alternative and mainstream Malaysian and Pakistani newspapers. They found that newspapers function per their ideologies by keeping their interests. In another study of Asad et al. (2019a), it was found that alternative online newspapers had given a fair representation of selected social actors compared to mainstream Malaysian online newspapers and maintained their institutionalized interests and ideologies. Noor (2015) found that mainstream Malaysian newspapers always appraise the government officials positively and give less representation to the opposition, leading to biased representation by mainstream newspapers.

In a study conducted on Pakistani online alternative and mainstream newspapers, similar findings were found that 'Dawn' represented social actors neutrally and 'The News' also given share to both social actors but came up with two governments' comparison with external voice to hide its stance towards existing government (Asad et al., 2019b). For the maintenance of the authorial voice, newspapers use rhetorical markers as an external supporting voice to win the readership (Sabao \& Visser, 2015). From the last five years studies it was found that the author maintains engagement with reader by his stances towards his point of views (Huan, 2016; Mugumya \& Visser, 2015; Nádraská, 2017; Sabao \& Visser, 2015; Tavassoli et al., 2018; van Driel, 2018; Zhang, 2015; Zhang \& Liu, 2015).
Appraisal Analysis
'Appraisal' theory by Martin and White (2005) was employed in the study for finding the stances from a dialogic as well as from a generic perspective of online newspapers. Appraisal analysis is an extension of Systemic Functional Linguistics (SFL) of Halliday's (1978) theory. It acts as an alternative approach for analyzing the discourse in linguistics of 'hard news' of newspapers that acts for their 
ideological functions and support journalists to imprint their voices (Sabao, 2016).

Martin and White (2005) explain the pattern choices semantically and organization of text that affect the reader for enhancing social values. They also explain the construction of stances and interpersonal relationships and positioning in 'Appraisal' theory. It concerns how the author positions his readers by criticizing or applauding and approving or disapproving (Martin \& White, 2005).

'Appraisal' theory explains writers' attitudinal stances towards discourses in their context based on shared feelings, emotions, assessments, and alignments, etc. of individuals by the authorial identities' construction (Martin \& White, 2005). The attitudinal stances are based on three semantic resources of discourse i.e. 'Attitude', 'Engagement' and 'Graduation'. The existing study is based on 'Attitude' resources. 'Attitudinal' resources are adjectival and convenient to develop framing grammatically (Martin \& White, 2005).

\section{Attitude in text}

'Attitude' in the text concerns the feelings, emotions, and judgments of behavior with the evaluation of things (Martin \& White, 2005). The attitudinal expressions convey positive or negative evaluations and are in form of 'inscribed' attitude (from writer's point of view). In contrast, indirect attitudinal meanings are 'invocations' (described through external resource) of attitudes (Tavassoli et al., 2018). The 'Attitudes' narrated in news reports are the ideology elements and influence the reader who can't stay away from it (Zhang, 2015).

The 'Attitudes' are divided into three categories i.e. 'Affect', 'Judgment' and 'Appreciation'. 'Affect' creates the reactions emotionally like anger, horror, worry, etc. It has four sub-resources i.e. 'un/happiness', 'In/Security', 'Dis/Satisfaction' and 'Dis/Inclination' (Martin \& White, 2005). 'Judgment' assesses behavior like miserly, badly, minatory, etc., while 'Appreciation' assessment creates the value of things like very nicely, beautifully, very lively, destruction, weirdly, as a bonus, etc. (Martin \& White, 2005). 'Judgment' has two types i.e. 'social sanction' and 'social esteem'. 'Social Sanctions' is responsible for evaluating the behavior by imposing a law or rule. It is categorized into two types, firstly 'Veracity' that deals with how truthful a person is and secondly, 'Propriety' to know a person's ethicality. Social 'esteem' concerns with 'normality' of judging how the unusual person is, 'capacity' deals with a person's capability and 'tenacity' deals with how much a person is truthful.

'Appreciation' depends on a person's performance and evaluates on that basis ('impact' e.g. exciting, dull, lively, etc. and 'quality' e.g. good, welcome, plain, nasty, etc. defines the terms).
It is further subdivided into three categories, firstly 'reactions' that are towards things secondly, 'composition' that is divided into 'Complexity' and 'Balance'. 'Complexity' evaluates things like simple, wooly, precise, etc. 'Balance' evaluates like shapely, flawed, consistent, uneven, etc. and lastly, the 'valuation' of judging depends on how innovative, pricey, creative, authentic, etc. a person is (Martin \& White, 2005).

\section{METHOD}

The semantic and interpersonal linguistic representation of Pakistani alternative and mainstream online newspapers were analyzed with Norman Fairclough's (1995) theory of Critical Discourse Analysis (CDA) that was employed under the 'Attitude' analysis that is sub-category of 'Appraisal Analysis' as an analytical tool of Martin and White (2005). Appraisal analysis is an extension of Halliday's (1978) Systemic Functional Linguistics (SFL) analytical tool where the text was analyzed by the framework of Martin and White (2005).

\section{Data collection and analysis procedure}

The news reports were selected from 'Dawn' and 'The News' on 74th United Nations' session speech of the prime minister of Pakistan, Imran Khan, delivered on 27th September 2019. The speech was given coverage by one each news report in detail by both newspapers. Two news reports were manually downloaded comprising of '5013' words in total. 'Dawn' had given representation with '2334' words, while; 'The News' came up with '2679' words. 'Dawn' published news report online immediately on the same day after the speech as current news and 'The News' published on next day i.e. 28th September 2019. The manually downloaded news reports were pasted in word then on the second stage on 'Excel' spreadsheet software package in form of clauses for the analysis based on 'Appraisal' and its 'Attitude' resource. At the last stage, the percentages were taken out to evaluate the attitudinal stances.

\section{FINDINGS AND DISCUSSION Attitudinal analysis}

This section explains the analysis of the results of two online newspapers in Pakistan. The 'Attitude' analysis was applied to newspapers' texts which included emotional values of responses which are 'Affect', the values which are assessed socially by the behavior of actor is 'Judgment'. Those values which address and explains the entities of qualities, natural phenomena and objects are 'Appreciation'. 'Attitude' involves 'Affect', 'Appreciation' and 'judgment'- three semantic regions: emotional, ethics and aesthetics (Martin \& White, 2005). In- 
text, 'Emotion' is above all regions. It is a resource of expression that plays the important and main part in the negotiation of stance by conveying the attitude and receiving the response to one's viewpoints in a social context (Martin \& White, 2005). The detailed analysis with distributions of attitudinal resources (keys) is discussed below.

Table 1 shows a comparison between the two online newspapers' discourses i.e. 'Dawn' as an alternative newspaper and 'The News' as a mainstream newspaper. The resources' rate of 'Attitude' is seen near to each other (appraisal items are analyzed per 100 words) as both newspapers have shown their stances higher in 'Judgment'. 'Dawn' shows with 75 instances with 54\%, while 'The News' comes up with 88 instances by scoring $53 \%$ in 'Judgment' resource.

Table 1

Distribution of Attitudinal Resources

\begin{tabular}{lcc}
\hline Feature & Instances in Dawn & Instances in The News \\
\hline Affect & $6(4 \%)$ & $6(4 \%)$ \\
Judgment & $75(54 \%)$ & $88(53 \%)$ \\
Appreciation & $58(42 \%)$ & $70(43 \%)$ \\
\hline
\end{tabular}

Table 1 shows that Appraiser 'Prime Minister of Pakistan, Imran Khan' has Appraised a lot in the 'Judgmental' resource, as seen in the following data:

Dawn 8: He said he would not have come to the UN if he did not feel that some "urgent issues" needed to be addressed. [Jud, pos (+) ten, Appraised (Urgent Issues), Appraiser (Imran Khan)].

The News 21: What are they going to do? When they come out? There will be a bloodbath. [Jud, neg

\section{(-) cap, Appraised (Indian Troops), Appraiser (Imran Khan)].}

Khan has represented Pakistan and come up with the issues which are supposed to be immediately solved to maintain peace in the region. The newspaper has given 28 occurrences with $27 \%$ in 'Capacity' resource under 'Judgment' that shows him focusing on capabilities of powerful leaders/people who can resolve the issue (table 2).

Table 2

Summary of Attitudinal Choices in 'Dawn'

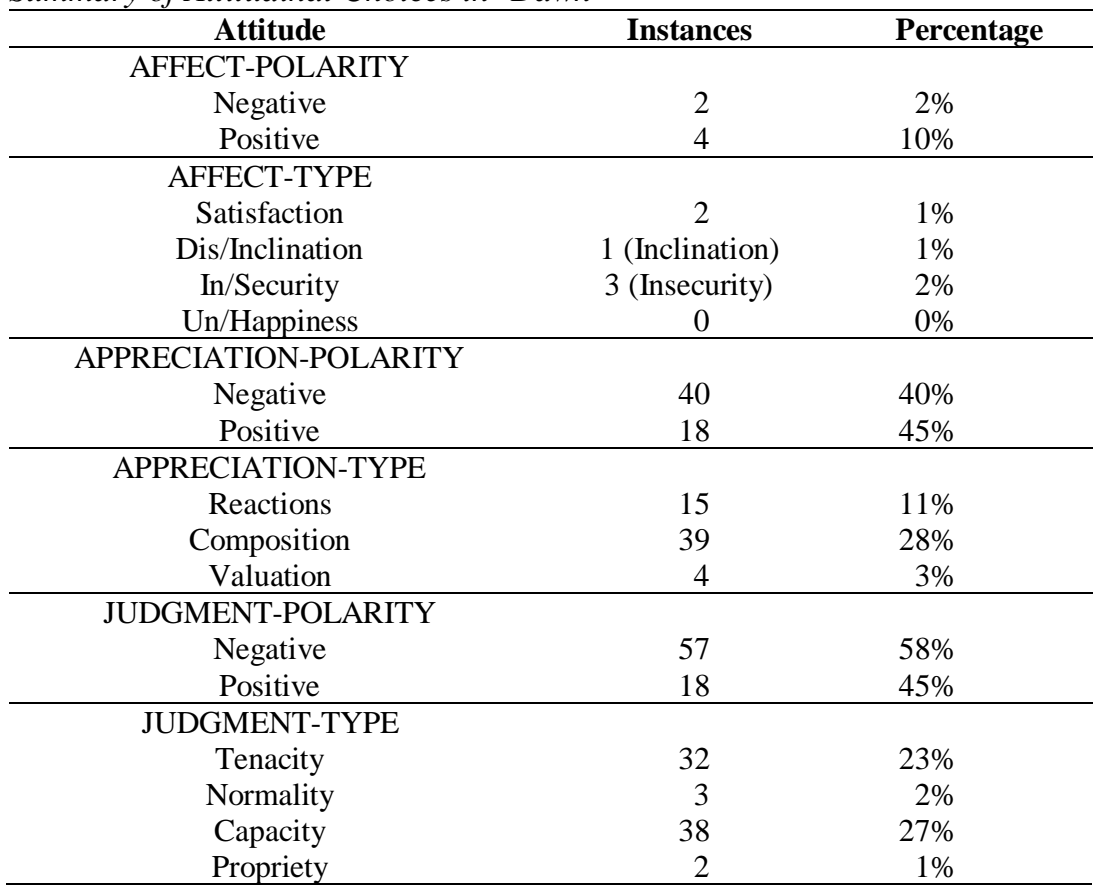

It is positive as well as negatively portrayed as still after 72 years of independence Kashmir issue is still unresolved and powerful people haven't come forward to resolve this. The following statements are showing the capabilities of people/rich countries to take action and show political will:
Unless the rich countries intend to build walls to stop economic refugees [from] coming as we see right now, they must take action

The rich countries must show political will. They cannot allow this to happen

In European countries, it is marginalizing Muslims, and this leads to radicalization. 
In the case of marginalizing Muslims in European countries, radicalization and European countries should understand Muslims' sentiments as Islam is the religion of peace. It does not promote terrorism. The explanation by Imran Khan clearly shows how he has portrayed the country's problems and sentiments of Muslims towards sacred places and Islamic religious personalities.

Table 3

Summary of Attitudinal Choices in 'The News'

\begin{tabular}{|c|c|c|}
\hline Attitude & Instances & Percentage \\
\hline \multicolumn{3}{|l|}{ AFFECT-POLARITY } \\
\hline Negative & 2 & $2 \%$ \\
\hline Positive & 2 & $5 \%$ \\
\hline \multicolumn{3}{|l|}{ AFFECT-TYPE } \\
\hline Satisfaction & 0 & $0 \%$ \\
\hline Dis/Inclination & 1 (Inclination) & $1 \%$ \\
\hline Security & 0 & $0 \%$ \\
\hline Un/Happiness & 2 (Happiness) + 1 (Unhappiness) & $1 \%+1 \%$ \\
\hline \multicolumn{3}{|l|}{ APPRECIATION-POLARITY } \\
\hline Negative & 38 & $37 \%$ \\
\hline Positive & 16 & $36 \%$ \\
\hline \multicolumn{3}{|l|}{ APPRECIATION-TYPE } \\
\hline Reactions & 19 & $13 \%$ \\
\hline Composition & 32 & $22 \%$ \\
\hline Valuation & 3 & $2 \%$ \\
\hline \multicolumn{3}{|l|}{ JUDGMENT-POLARITY } \\
\hline Negative & 62 & $61 \%$ \\
\hline Positive & 26 & $59 \%$ \\
\hline \multicolumn{3}{|l|}{ JUDGMENT-TYPE } \\
\hline Tenacity (social esteem) & 43 & $29 \%$ \\
\hline Normality (social esteem) & 4 & $3 \%$ \\
\hline Capacity (social esteem) & 39 & $27 \%$ \\
\hline Propriety (social sanction) & 2 & $1 \%$ \\
\hline
\end{tabular}

The main issue of recent Kashmir conflict was raised, a source of the main conflict between Pakistan and India. Imran Khan represented as the main 'Appraiser' in both newspapers. He represented the country on the United Nations' 74th Session. Both newspapers quoted his speech by direct quotes mostly. The words raised by him to aware the world leaders about Kashmir by using like 'Kashmiris', 'Issues', 'bloodbath', 'India and Pakistan', 'Prime Minister Narendra Modi', 'Islam phobia', 'Indian Troops', 'Muslim Women', 'War', 'Terrorism', 'Aryan Superiority', Modi's Arrogance', 'Curfew', 'People of Kashmir', 'SelfDetermination', 'International Community', Conventional War', 'Fight', 'Action', 'Cruelty on Kashmiris', 'Indian Muslims', 'Muslims', 'Soldiers', 'RSS Ideology', 'Urgent Issue', 'Radicalization' etc.

Using these words in his speech he portrayed the picture and cruelty being faced by Kashmiris from India. He was on the view of giving selfdetermination to Kashmir people as they have a right as per the Constitution of India and the 'Shimla Accord' between two countries. Both countries are determined to fight until the end to have their land. India without consultation violated the decided terms and has included the disputed region of Kashmir into its territory. Imran Khan made aware the world leader as both countries are nuclear power so; there is a need for mediation of the United Nations to come up with a solution.
On the second number, both newspapers have represented the speech higher in the 'Appreciation' resource. 'Dawn' has given 58 instances with $42 \%$ and 'The News' comes up with 70 instances with $43 \%$ (table 3). The words like 'Curfew', 'Kashmiris', 'Cruelty on Kashmiris', 'World', 'India \& Pakistan', 'India', 'Actions by India', 'Conventional War', etc. have used to 'Appreciate' negatively the issue. The outcomes were highlighted which were created from the current issue. Imran Khan positively appreciated the United Nations' role as a mediator. But in both newspapers, the negative 'Appreciation' resource is higher as 'Dawn' had shown 40 instances in the negative category with $40 \%$ (table 2) while 18 instances with positive 'Appreciation resource by $45 \%$ as in the following data.

Dawn 240: Why shouldn't rich people pay taxes? Why are they legal, these secret accounts? [App, neg (-) comp, Appraised (rich people), Appraiser (Imran Khan)].

The News 293: He had met President Rohani and hoped that peace would prevail in Gulf. [App, pos (+) comp, Appraised (Gulf Tension), Appraiser (Imran Khan)].

In the third category of 'Attitude' analysis i.e. 'Affect', it is seen that very few author emotional affects have been represented. 'Affect' concerning the registration of personal feelings like, happy, sad, 
confident, bored, etc. In 'Dawn', journalists come up with $2 \%$ with 3 occurrences in 'Insecurity' resource and 2 occurrences with $1 \%$ in 'Satisfactory' resource. In comparison 'The News' has shown $1 \%$ in 'Inclination' and $1 \%$ in 'Unhappiness' resource and represented by $1 \%$ by 2 occurrences in 'Happiness' emotional resource (table 2 and 3). By quoting the author's direct source, the journalist stays himself back by putting the responsibility on the speaker to give an authentic and incontrovertible source (Bell, 1991). Few examples of 'Affect' resource are;

Dawn 6: The premier began his wide-ranging, at times extemporaneous speech by saying he feels honored to represent Pakistan at the world forum. [Aff, pos (+) satis, Appraised (Pakistan), Appraiser (Imran Khan)]

The News 5: The meeting comes amid simmering tension in the Middle East over recent attacks on Saudi Arabian oil facilities, which the United States blames on Iran, allegations Tehran denies. [Aff, neg
(-) incli, Appraised (Meeting), Appraiser (Imran Khan)].

In both newspapers the journalist's voice is not heard, they have taken the authorial stance through the voice of the speaker instead of a journalist. The readers are provided with positive and negative inscribed and invoked stances. In 'Dawn' it is seen that only ' 1 ' positive inscribed and ' 2 ' negative inscribed stances have been quoted (table 4). The speech is all related to issues that were being faced and they were represented the most by negative invoked stances by 96 instances and positive invoked stances were found by 39 instances. On the other side in comparison to 'The News', it was found that again 'The News' portrayed the maximum with 98 negative invoked instances and positive invoked instances were 42 . The positive inscribed instances were ' 2 ' and the negative inscribed instance was only ' 1 ' in the newspaper (table 4).

Table 4

Positive, Negative, Inscribed and Invoked Instances

\begin{tabular}{lrlr}
\hline \multicolumn{1}{c}{ Dawn } & Instances & \multicolumn{1}{c}{ The News } & Instances \\
\hline Positive Inscribed & $1(33 \%)$ & Positive Inscribed & $2(33 \%)$ \\
Negative Inscribed & $2(67 \%)$ & Negative Inscribed & $4(67 \%)$ \\
Positive Invoked & $39(29 \%)$ & Positive Invoked & $42(30 \%)$ \\
Negative Invoked & $96(71 \%)$ & Negative Invoked & $98(70 \%)$ \\
\hline
\end{tabular}

Overall importance to Kashmir issue was given but Pakistan's other immediate problems of 'Climate Change' and 'Islam phobia' were also explained by PM Imran Khan to world leaders. He believed that their positive steps would be encouraged by their investments in the country for tackling the issue. The negative impression of Islam in the western world was explained as a peaceful religion, as other religions are sensitive to their religion, so Muslims also react when they hear negativity about Islam. He was on the view that all world leaders and the UN have a responsibility to help the developing country like Pakistan to solve its issues and step forward to help. The following stances explain Khans' views that are evaluated from the context i.e.

Dawn 194: He noted that Pakistan is in the top ten list of countries that are most affected by climate change. [App, neg (-) comp, neg (-) invoked, Appraised (Pakistan \& Climate Change), Appraiser (Imran Khan)]

The News 190: He said Muslims were being marginalized in Europe. [Jud, neg (-) cap, neg (-) invoked, Appraised (Muslims), Appraiser (Imran Khan)]

The readers are given a comparison in positive and negative, inscribed and invoked stances' presentation by newspapers. By analyzing the results of 'Dawn' and 'The News', it is found that both newspapers want to divert readers as per their viewpoints and applied rhetorical markers by quoting the sayings mostly of the social actor (Imran Khan) and in this way they represented the news institutions' ideology from an external source. The application of the CDA framework with subcategory of 'Appraisal Analysis' i.e 'Attitude' analysis has provided the reader with the background information with the knowledge of different stances on the representation of news reports. The study of Alsanafi and Mohd (2019) shows the similar findings where the old created impression of African Black women in context could be found the same in postmodern American plays (dramas). It is also similar in the case of PM Imran Khan's speech where the representation of the event depicts the newspaper ideology. The event is considered important from the national point of view, and both newspapers presented the same news with minor changes in representation. The current relationship status and ongoing issues between Pakistan and India had been taken as an important coverage by considering the past relations. The findings in the form of frequencies are supporting the research objective ' 3 '. Wodak and Meyer (2009) stated that CDA is a beneficial tool of analysis for establishing and reproducing power relations in discourse. By opting CDA with 'Attitude Analysis', the power relation of news institutions was found with the representation of issues raised by Prime Minister, which depicts the ideology of news organization as to how they have taken the help of 
rhetorical markers for the representation of news report. Both newspapers have given prominent coverage and shown maximum similarities with minor differences in percentage in representation. The Prime Minister's speech on an international platform was well represented with the timings' difference of coverage as 'Dawn' appeared online on the same day late in the evening after PM speech and 'The News' came up on the second day.

The findings were similar to the study of Sabao and Visser (2015) that attributed resources in the form of quoting external voice as authority serves as reinforcement. In this way, journalist takes help of attributed resource to convey his point of view and keeps himself at a distance from taking the responsibility of said statement. Fairclough (1995) stated that the evaluation of patterns and social actors' representation shows the social practices that appear as a discursive process in text production. The similar findings were also found in another study of Sabao (2016) that attribution resources were employed for clinching personalization by hiding the news institution's voice for the maintenance of objectivity in the hard news reporting. The attributed voice becomes the authority in the quoted text that frees journalist from any sort of responsibility. The external/attributed resource becomes the main actor behind the representation of news. The findings of the current study are supporting research objective ' 2 ' by the representation of news reports in the quoted text of the speaker for maintaining the actual source to show the objectivity of news reporting. Butt et al. (2010) quoted in the study of Noor (2015) that text has different flavours and resources like an appraisal, lexicogrammar, and attitude are known as beneficial tools for exploring attitudinal flavors.

It is a new framework of two online newspapers i.e. 'Dawn' (alternative online newspaper) and 'The News' (mainstream online newspaper) to study on 'Prime Minister Imran Khan's speech on 74th UN session' by 'Attitude Analysis'. The combination of both streams of newspapers determine their inclination toward the head of government. It is found that both newspapers used attributed external resource and given coverage as an important event without missing any focal points. The detailed coverage is found in both newspapers. At the global level, both newspapers have given impression the same by handling the event as top priority where prime minister of Pakistan quoted the most with his statements. Therefore, in contextual implication, the study highlights the influential factors that affected the text to be presented the same. From the practical implication, the analysis would give in-depth insight into the newspapers' representation and political issues among Pakistan and India whereas, textual and theoretical application highlights the literature gap that fills up with the grammatical analysis. The significance of study lies in the representation of news reports by alternative and mainstream newspapers. The students would be able to understand and can apply the same framework to find the ideology of newspapers. Further future studies can be conducted by the consideration of 'CDA' and 'Appraisal Analysis' on alternative and mainstream newspapers for analyzing the different stances' creation in the existing media culture of a country.

\section{CONCLUSION}

It is found that the alternative and mainstream newspapers have dealt the speech on top priority by considering the important platform for conveying Pakistan's vital threats in an existing political context and given prominent coverage. As per 'Dawn' reputation in Pakistani culture, it was found that it had given immediate coverage online on the same day by considering the news to be disseminated immediately as current fresh news by Prime Minister of Pakistan. On the other hand, 'The News' came up with extensive coverage of PM speech but it appeared online the next day. Both newspapers had used rhetorical markers extensively (social actor-PM Imran Khan) to support their stances. Both newspapers showed a positive attitude in representing a particular news report and seen on one agenda by adopting the same pattern of representation. 'The News' especially avoided its past relations with Pakistan Tehreek-e-Insaaf (PTI) and PM Imran Khan by coming up with the same agenda as 'Dawn' on particular news. By the 'Attitude Analysis,' both newspapers have revealed the writer's and speaker's emotions/feelings and can relate to the authority construed in the text (Martin \& White, 2005).

\section{REFERENCES:}

Allan, S. (2010). News Culture-Ch\#2, The rise of objective news reporting. McGraw-Hill Education.

Alsanafi, I., \& Mohd, S. (2019). Development of black feminine identity in two postmodern American plays through appraisal framework: Comparative study. Amazonia Investiga Journal, 8 (21), 104-116. https://amazoniainvestiga.info/index.php/amaz onia/article/view/52

Asad, S., Noor, S. N. F. M., \& B. Jaes, L. (2019a). Social actors' representation in online Malaysian newspapers during elections: A transitivity analysis of newspaper text.

Humanities \& Social Sciences Reviews, 7(4), 580-589.

https://doi.org/10.18510/hssr.2019.7478

Asad, S., Noor, S. N. F. M., \& B. Jaes, L. (2019b). Linguistic representation of 100 days of Pakistan Tehreek-e-Insaaf in online Pakistani 
newspapers: A critical discourse analysis \& systematic functional linguistic perspective. International Journal of Engineering and Advanced Technology (IJEAT), 8(5C), 12001207. https://doi.org/10.35940/ijeat.e1170.0585c19

Asad, S., Noor, S., Binti, F., Mohd, N., \& Jaes, L. Bin. (2019c). Transitivity analysis of election coverage in online newspapers of Malaysia \& Pakistan: A study with critical discourse analysis \& systematic functional linguistics' perspective. Amazonia Investiga Journal, 8(21), 168-176.

https://www.amazoniainvestiga.info/index.ph p/amazonia/article/view/85

Bagdikian, B. (2007). Media monopoly. Television Quarterly, 28(4), 29-40. https://doi.org/10.1002/9781405165518.wbeo sm065

Bell, A. (1991). The language of news media (Vol. 15). Basil Blackwell Ltd.

Fairclough, N. (1995). Critical discourse analysis: The critical study of language. Longman Group limited. Longman Group Limited.

Foucault, M. (1980). Power/knowledge: Selected interviews and other writings. Pantheon Books.

Habermas, J. (2006). Political communication in media society: Does democracy still enjoy an epistemic dimension? The impact of normative theory on empirical research. Communication Theory, 16(4), 411-426. https://doi.org/10.1111/j.14682885.2006.00280.x

Haig, E. (2012). A critical discourse analysis and systemic functional linguistics approach to measuring participant power in a radio news bulletin about youth crime. Studies in Media and Society, 4, 45-73. https://doi.org/10.18999/STUMS.4.45

Halliday, M. A. K. (1978). Language as a social semiotic. Hodder Arnold

Halliday, M. A. K. (1999). Text \& context in functional linguistics-the notion of "context" in language education. (M. Ghadessy, Ed.). John Benjamins Publishing.

Huan, C. (2016). Journalistic engagement patterns and power relations: Corpus evidence from Chinese and Australian hard news reporting. Discourse \& Communication, 10(2), 137-156. https://doi.org/10.1177\%2F175048131561123 9

Janks, H. (1997). Critical discourse analysis as a research tool. Discourse: Studies in the Cultural Politics of Education, 18(3), 329342. https://doi.org/10.1080/0159630970180302

Jóhannsdóttir, V. (2018). Commercialization in the Icelandic Press: An analysis of hard and soft news in major print and online media in
Iceland in times of change. Journalism, 1(17), 1762-1778. https://doi.org/10.1177/1464884918768494

Khan, L. A. (1994). The Kashmir dispute: A plan for regional cooperation. Columbia Journal of Transnational Law, 31(3), 495-550. https://ssrn.com/abstract $=987561$

Ksiazek, Thomas B, Peer, L. \&, \& Lessard, K. (2016). User engagement with online news: Conceptualizing interactivity and exploring the relationship between online news videos and user comments. New Media \& Society, 18(3), 502-520. https://doi.org/10.1177/1461444814545073

Malik, S., \& Iqbal, Z. (2011). Construction of Taliban image in Pakistan: Discourse analysis of editorials of Dawn and The News. China Media Research Journal, 7(2), 46-56.

Martin, J. R., \& White, P. R. R. (2005). The language of evaluation. Palgrave Macmillan.

Masood, S. (2018, November). Pakistan angered by Trump's claim that it does 'nothing' for U.S. The New York Times.

https://www.nytimes.com/2018/11/19/world/a sia/pakistan-trump-imran-khan.html

Mugumya, L., \& Visser, M. (2015). Reporting land conflict in Uganda: A genre and appraisal theoretical analysis of Runyankore-Rukiga newspaper reports. International Journal of Language and Culture, 2(1), 108-131. https://doi.org/10.1075/ijolc.2.1.05mug

Nádraská, Z. (2017). The functions of external voices in hard news Appraisal: A dialogic perspective. Topics in Linguistics, 18, 63-80. https://doi.org/10.1515/topling-2017-0011

Noor, S. F. B. M. N. (2015). Empowering the powerful: A critical discourse analysis of public discourse on graduate employability. [Doctoral dissertation]. Sydney, Macquaire University. Retrieved from http://eprints.uthm.edu.my/9136/1/Siti_Noor_ Fazelah_Mohd_Noor.pdf.

Ononye, C. F. (2017). Lexico-stylistic choices and media ideology in newspaper reports on Niger Delta conflicts. Indonesian Journal of Applied Linguistics, 7(1), 167-175. https://doi.org/10.17509/ijal.v7i1.6870

Page, B. (1996). The Mass media as political actors. Political Science \& Politics, 29(1), 20-24. https://doi.org/10.2307/420185

Richardson, J. E. (2007). Analyzing newspapers. Palgrave Macmillan.

Sabao, C. (2016). Arguments for an appraisal linguistic discourse approach to the analysis of 'objectivity' in 'hard' news reports. African Journalism Studies, 7(1), 40-63. https://doi.org/10.1080/23743670.2015.10957 76

Sabao, C., \& Visser, M. (2015). Evaluating authorial "objectivity" and "stance taking" in reporting 
the making of a new constitution in Zimbabwean newspapers. CommunicatioSouth African Journal for Communication Theory and Research, 41(1), 43-70. https://doi.org/10.1080/02500167.2015.10111 78

Schudson, M. (2002). The news media as political institutions. Annual Review of Political Science, 5(1), 249-269. https://doi.org/10.1146/annurev.polisci.5.1112 01.115816

Tavassoli, F., Jalilifar, A., \& White, P. R. R. (2018). British newspapers' stance towards the Syrian refugee crisis: An appraisal model study. Discourse \& Society, 30(1), 1-21. https://doi.org/10.1177/0957926518801079

Thomas, P., \& Selimovic, A. (2015). "Sharia on a Plate?" A critical discourse analysis of halal food in two Norwegian newspapers. Journal of Islamic Marketing, 6(3), 331-353. https://doi.org/10.1108/jima-05-2014-0041

van Driel, M. A. (2018). Online news reporting: A comparative textual analysis of hard news live blogs and traditional online news articles and a reader response analysis using appraisal [doctoral thesis]. University of Birmingham. van Leeuwen, T. (2008). Discourse and practice.
Oxford University Press.

Wodak, R. (2006). Mediation between discourse and society: Assessing cognitive approaches in CDA. Discourse Studies, 8(1), 179-190. https://doi.org/10.1177/1461445606059566

Wodak, R., \& Meyer, M. (2009). Critical discourse analysis: History, agenda, theory, and methodology 1. Methods for Critical Discourse Analysis, (November), 1-33.

Zaidi, A. (2016). Covering faith-based violence: Structure and semantics of news reporting in Pakistan from book Faith-based violence and Deobandi militancy in Pakistan. (J. Syed, E. Pio, T. Kamran, \& A. Zaidi, Eds.). Palgrave Macmillan.

Zhang, W., \& Liu, W. (2015). One coin has two sides: A comparative appraisal of New York Times and China Daily's News coverage of alleged internet hacking. Journal of Arts \& Humanities, 4(4), 1-15. https://doi.org/10.18533/journal.v4i4.681

Zhang, X. (2015). Comparative study on the appraisal resources of China Daily's disaster news. Theory and Practice in Language Studies, 5(10), 2118-2130. https://doi.org/10.17507/tpls.0510.20 